\title{
Clinicoepidemiological Profile, Risk Factors and Outcome of Severe Acute Malnutrition Children at the Nutritional Rehabilitation Centre of a Tertiary Care Centre in Eastern India- A 4 Years Experience
}

\author{
Suman Das*, Dilip Kumar Paul, Mala Bhattacharya, Suprit Basu, Anish Chatterjee, Sandip Sen and Subhojit \\ Bhakta
}

Residential Medical Officer cum Clinical Tutor, Department of Pediatrics, India

Submission: March 02, 2017; Published: May 03, 2017

"Corresponding author: Suman Das, Residential Medical Officer cum Clinical Tutor, Department of Pediatrics, Dr. BC Roy Post Graduate Institute of Pediatric Sciences, Kolkata, West Bengal, India, Email: dr.sumands@gmail.com

Abstract

Background-India is home to the greatest population of severely malnourished children in the world. This present study evaluates the clinical and epidemiological profile of children admitted with severe acute malnutrition (SAM) and assessment of the precipitating factors of SAM and evaluates the effectiveness of nutritional rehabilitation centre (NRC) in providing therapeutic care for children.

Methods: An observational prospective hospital based study in which all children under-5 years admitted in NRC over a period from January 2013-December 2016 were enrolled. Variables recorded were demographics, anthropometry, clinical presentation, laboratory tests, medical complications, outcome indicators and hospital course.

Results: Mean age of admitted children was $17.21 \pm 13.94$ months and mostly belonged to lower socio-economic scale, rural areas and large families. 9.2\% were less than 6 months at time of admission. Male: female ratio was 1:1.24. Most common associated infections were acute respiratory tract infections (35.87\%), and diarrhoea (31.75\%). Anaemia was an important co-morbidity (74.12\%). Mean duration of exclusive breastfeeding was $3.1 \pm 1.8$ months and mean age of starting semi-solid complementary food was $8.5 \pm 2.5$ months. Most commonly used supplementary food was over diluted cow milk (92\%). Cure rate was $75.24 \%$. Defaulter rate was $13.65 \%$ and death rate was $0.63 \%$.

Conclusion: The problem of SAM is multidimensional and NRCs provide life-saving care for children as demonstrated by the high survival rates.

Keywords: Severe acute malnutrition; Nutritional rehabilitation centre; Cure; Follow-up

\section{Introduction}

Out of 19 million SAM child in all developing countries, 8 million (42\%) are in India. National family health survey-3 (2005-2006) show that $42.5 \%$ of Indian children $<5$ years were underweight, $48 \%$ were stunted, $17 \%$ were wasted and $6.4 \%$ suffer from SAM and these SAM children have high mortality ranging from $20 \%-30 \%$ [1]. The prevalence of malnutrition varies across states like Madhya Pradesh recording the highest rate (55\%) and Kerala among the lowest (27\%) [2]. This is believed to be due to a combination of socio-economic and societal factors including poverty, food insecurity, gender inequality, disease and poor access to health and developmental services [2,3]. Recovery rates in inpatient facilities to treat SAM children (NRCs) varied from state to state ranging from $37.1 \%$ to $65 \%[4,5]$.

There is no published community/hospital based studies of SAM children in eastern India; hence the present study was conducted (Table 1).

\section{Objectives}

1) To evaluate the clinico-epidemiological profile, complications, and comorbidities of SAM children.

2) To identify the socio-demographic risk factors of SAM and 
3) To evaluate the outcome of hospitalized SAM children.

\section{Methods and Materials}

i. Study type: Observational

ii. Study design: Observation model - cohort, Time perspective-prospective.

iii. Study centre: NRC at Dr B.C. Roy Post Graduate Institute of Pediatric Sciences, Kolkata (a tertiary care and referral centre).

iv. Study duration: January 2013-December 2016

Informed consent was obtained from the parents of all the children. Institutional ethical committee approval was taken (BCH/ME/PR/147).

\section{Inclusion criteria}

For 6 months -5 years age group: presence of any of the following

a) Weight for length/height<-3 standard deviation (SD) [World Health Organisation (WHO) median height].

b) Bilateral pedal edema.

c) Grossly visible severe wasting.

d) Mid upper arm circumference $<11.5 \mathrm{~cm}$.

For 1-6 months age group- presence of any of the following

a) For infants $>45 \mathrm{~cm}$ length, weight for height $<-3 \mathrm{SD}$ with or without bipedal edema.

b) For infants $<45 \mathrm{~cm}$ length, visible severe wasting was used to define SAM.

c) Presence of edema both feet.

At enrolment into the study, anthropometric parameters, socio-demographic variables, feeding practices [duration of Results and Analysis (Table 2)

Table 2: Characteristics of SAM children over the 4 years period.

\begin{tabular}{|c|c|c|c|c|c|c|c|c|c|}
\hline Year & $\begin{array}{c}\text { Total } \\
\text { patient }\end{array}$ & Male & Female & $<6$ month & $\begin{array}{c}\text { 6-12 } \\
\text { months }\end{array}$ & $\begin{array}{c}12-24 \\
\text { months }\end{array}$ & $\begin{array}{c}24-36 \\
\text { months }\end{array}$ & $\begin{array}{c}36-48 \\
\text { months }\end{array}$ & $\begin{array}{l}48-60 \\
\text { months }\end{array}$ \\
\hline 2013 & 170 & 78 & 92 & 16 & 52 & 62 & 22 & 13 & 5 \\
\hline 2014 & 156 & 75 & 81 & 15 & 49 & 56 & 21 & 11 & 4 \\
\hline 2015 & 134 & 52 & 82 & 12 & 42 & 48 & 18 & 10 & 3 \\
\hline 2016 & 170 & 76 & 94 & 15 & 52 & 62 & 24 & 12 & 6 \\
\hline Total & 630 & 281 & 349 & 58 & 195 & 228 & 85 & 46 & 18 \\
\hline
\end{tabular}




\section{Advanced Research in Gastroenterology \& Hepatology}

The male and female ratio was $281: 349$ (1:1.24). The mean ages of SAM patients were 17.21 \pm 13.94 months (sample standard variance- 194.56 and population standard variance-193.78.) (Table 3).

Table 3: Social and dietary factors attributing to SAM.

\begin{tabular}{|c|c|c|}
\hline Literacy status of parents & Number & $\%$ \\
\hline Maternal illiteracy & 145 & 23.01 \\
\hline Mother studied up to primary and middle school & 262 & 41.58 \\
\hline $\begin{array}{c}\text { Mother studied up to high school and } \\
\text { intermediate }\end{array}$ & 218 & 34.6 \\
\hline Mother graduated, postgraduate professionals & 5 & 0.79 \\
\hline Paternal illiteracy & 119 & 19 \\
\hline Father studied up to primary and middle school & 315 & 50 \\
\hline $\begin{array}{c}\text { Father studied up to high school and } \\
\text { intermediate }\end{array}$ & 189 & 30 \\
\hline Father graduated, postgraduate professionals & 7 & 1.11 \\
\hline
\end{tabular}

Socioeconomic status as per modified Kuppuswamy scale

\begin{tabular}{|c|c|c|}
\hline Upper (I) & 0 & 0 \\
\hline Upper middle (II) & 12 & 1.90 \\
\hline Lower middle (III) & 20 & 3.18 \\
\hline Upper lower (IV) & 230 & 36.50 \\
\hline Lower (V) & 368 & 58.41 \\
\hline \multicolumn{3}{|c|}{ Awareness of malnutrition } \\
\hline Yes & 158 & 25 \\
\hline No & 472 & 75 \\
\hline \multicolumn{3}{|l|}{ Sanitation facilities } \\
\hline Present & 504 & 80 \\
\hline Absent & 126 & 20 \\
\hline \multicolumn{3}{|l|}{ Immunisation status } \\
\hline Unimmunised & 40 & 4.35 \\
\hline Partly immunised & 540 & 85.71 \\
\hline Fully immunised & 50 & 7.94 \\
\hline \multicolumn{3}{|l|}{ Familial status } \\
\hline More than 3 children & 322 & 51.11 \\
\hline Joint families & 63 & 10 \\
\hline \multicolumn{3}{|l|}{ Residence } \\
\hline Urban & 158 & 25 \\
\hline Rural & 472 & 75 \\
\hline \multicolumn{3}{|l|}{ Feeding practices } \\
\hline Prelacteal feeds & 201 & 32 \\
\hline Colostrum given & 400 & 39 \\
\hline Exclusive breast feeding upto 6 months & 63 & 10 \\
\hline Mixed feeds & 567 & 90 \\
\hline Bottle feeds & 289 & 45.82 \\
\hline $\begin{array}{l}\text { Children initiated on semisolid/solid } \\
\text { complementary feeds at admission }\end{array}$ & 512 & 81.27 \\
\hline Adequacy of complementary feeds & 189 & 30 \\
\hline
\end{tabular}

Mean per capita income was Rs $980 \pm 600$. Exclusive breastfeeding was carried out up to 1 month in 554(87.94\%), up to 2 months in $469(74.50 \%)$ children, up to 3 months in $302(47.93 \%)$, up to 4 months in $167(26.48 \%)$ children, and up to 5 months in $75(12.05 \%)$ children. Mean duration of exclusive breast-feeding was $3.1 \pm 1.8$ months. Thereafter, they were started on mixed feeds. Most commonly used supplementary food among mixed feed infants $<6$ months was over-diluted cow's milk in 445(70.63\%) and rest 122(19.36\%) used over diluted commercially available formulas. The most common semi-solid complementary feed used was khichdi (rice-pulses gruel) in $144(22.86 \%)$ children, barley gruel in $134(21.27 \%)$ children, semolina porridge in $108(17.14 \%)$ children and mashed biscuits in $126(20 \%)$ children. $60(9.52 \%)$ children $>6$ months had not been introduced semi-solid complementary feeds at time of admission and were being given only diluted cow's milk at time of admission. Out of these 60 children, 36 were between 6-7 months, 14 were between 7-8 months and rest 10 was between 8-9 months of age. The mean age of starting semi-solid complementary food was $8.5 \pm 2.5$ months. According to IMNCI guidelines, adequate complementary feeds mean semi-solid/ solid/soft food-one 'katori' serving 3 times/day if breastfed and 5 times/day if not breastfed among 6-12 months children, and one and half 'katori' serving 5 times/day among >12 months children, which was present in only $30 \%$ children in our study (Table 4).

Table 4: Clinical characteristics and complications in SAM children.

\begin{tabular}{|c|c|c|}
\hline Characteristics & Number & $\%$ \\
\hline Oedema & 34 & 5.4 \\
\hline Anemia (MCHC<33) & 467 & 74.12 \\
\hline Skin changes & 190 & 30.16 \\
\hline Hair changes & 220 & 34.92 \\
\hline Signs of vitamin B deficiency & 262 & 41.59 \\
\hline Signs of vitamin C deficiency & 4 & 0.63 \\
\hline Signs of vitamin A deficiency & 205 & 32.54 \\
\hline Hypothermia & 128 & 20.31 \\
\hline Hypoglycaemia (capillary blood glucose<54 & 19 & 3.02 \\
\hline mg\%) & 65 & 10.31 \\
\hline Mental changes & 80 & 12.70 \\
\hline Hyponatremia & 75 & 11.90 \\
\hline Hypokalemia & 200 & 31.75 \\
\hline AGE(acute gastroenteritis) & 5 & 0.79 \\
\hline Shock & 226 & 35.87 \\
\hline ARI(acute respiratiry infections) & 15 & 2.38 \\
\hline UTI (urinary tract infection) & 4 & 0.63 \\
\hline Tuberculosis (TB) & 150 & 23.81 \\
\hline Developmental delay & 8 & 1.26 \\
\hline Septicaemia & 50 & 7.94 \\
\hline Otitis media & 5.79 \\
\hline
\end{tabular}




\begin{tabular}{|c|l|l|}
\hline HIV infection & 2 & 0.31 \\
\hline Malaria & 2 & 0.31 \\
\hline Measles & 4 & 0.63 \\
\hline
\end{tabular}

MCHC- mean corpuscular haemoglobin concentration

Among 34 patients with oedema, 7 were children $<6$ months of age. Among anaemic patients, $30(4.76 \%)$ had haemoglobin $<4 \mathrm{gm} \%$ and hence were given packed erythrocyte transfusion. Mean haemoglobin level was 8.45 $\pm 5.34 \mathrm{gm} \%$. Skin changes included flaky-paint dermatoses, desquamation, ulceration, which were mainly seen in the buttocks, perineum and upper thighs. Signs of vitamin B deficiency involved smooth tongue, cheilosis, and angular stomatitis. Hair changes included depigmentation, lustreless sparse hair. Mental changes included apathy, irritability, and unhappiness. Among 5 children with shock, 3 presented with septic shock and 2 had hypovolemic shock due to profuse watery diarrhea. Developmental milestones were assessed by Denver Developmental Screening Test. Among 4 patients with TB, 1 had tubercular peritonitis and 1 had progressive primary TB and 2 had primary complexes on chest skiagram. All had negative Mantoux test (due to depressed cell mediated immunity), but had positive CBNAAT in gastric aspirate. Skin infections included bacterial infections (folliculitis, boils, pyoderma) fungal infections (tinea, candidiasis) (Table 5).

Table 5: Enumerating the diagnostic criteria used to diagnose SAM children.

\begin{tabular}{|c|c|c|c|c|c|}
\hline Age & MUAC<11.5cm & Wt/ht<-3SD & Both & Edema & $\begin{array}{c}\text { Visible severe } \\
\text { wasting }\end{array}$ \\
\hline$>6$ month & $54(9.44 \%)$ & $185(32.34 \%)$ & $304(53.15 \%)$ & $29(5.07 \%)$ & $15(25.86 \%)$ \\
\hline$<6$ month & & $36(62.07 \%)$ & & $7(12.07 \%)$ & \\
\hline
\end{tabular}

Significant increase in mean MUAC occurred during NRC stay, $10.98 \pm 2.45 \mathrm{~cm}$ at admission versus $11.87 \pm 1.01 \mathrm{~cm}$ at discharge (one sided $\mathrm{t}$ value $=8.3294, \mathrm{p}<0.001$ ). Significant increase in mean weight also occurred, $6.36 \pm 4.25 \mathrm{~kg}$ at admission versus
$7.25 \pm 4.87 \mathrm{~kg}$ at discharge (one sided t value $=3.3033, \mathrm{p}<0.001$ ). Mean weight gain was $0.89 \pm 0.62 \mathrm{~kg}$. Mean duration of hospital stay was $20 \pm 0.35$ days. Average weight gain was $6.99 \mathrm{gms} / \mathrm{kg} /$ day.

Table 6: Showing the outcome of SAM children.

\begin{tabular}{|c|c|c|c|c|c|}
\hline Year & Total & Cured (\%) & Non-responder (\%) & Death (\%) & Defaulter (\%) \\
\hline 2013 & 170 & $115(68.52)$ & $27(15.88)$ & $2(0.31)$ & $26(15.29)$ \\
\hline 2014 & 156 & $124(79.50)$ & $12(7.69)$ & $1(0.64)$ & $19(12.17)$ \\
\hline 2015 & 134 & $104(77.62)$ & $11(8.21)$ & $1(0.74)$ & $18(13.43)$ \\
\hline 2016 & 170 & $131(77.07)$ & $16(9.41)$ & 0 & $23(13.52)$ \\
\hline Total & 630 & $474(75.24)$ & $66(10.47)$ & $4(0.63)$ & $86(13.65)$ \\
\hline
\end{tabular}

Recovery or cure indicates the number of beneficiaries that have reached discharge criteria. Defaulters indicate a SAM child admitted to the ward but absent from the ward for 3 consecutive days, without being discharged. Non-responders indicate those be neficiaries who fail to respond to the treatment (patient remains for a long period of time below the target weight) (Table 7) [6].

Table 7: Showing the follow-up details of SAM children.

\begin{tabular}{|c|c|c|c|c|c|c|c|c|c|}
\hline Year & $\begin{array}{l}\text { Patients } \\
\text { called for } \\
\text { follow- } \\
\text { up }\end{array}$ & $\begin{array}{c}1^{\text {st }} \\
\text { follow- } \\
\text { up }\end{array}$ & $\begin{array}{c}\text { Drop out } \\
\text { (\%) }\end{array}$ & $\begin{array}{c}2^{\text {nd }} \\
\text { follow- } \\
\text { up }\end{array}$ & $\begin{array}{c}\text { Drop out } \\
\text { (\%) }\end{array}$ & $\begin{array}{c}3^{\text {rd }} \\
\text { follow- } \\
\text { up }\end{array}$ & $\begin{array}{c}\text { Drop out } \\
\text { (\%) }\end{array}$ & $\begin{array}{c}4^{\text {th }} \\
\text { follow- } \\
\text { up }\end{array}$ & $\begin{array}{c}\text { Drop out } \\
(\%)\end{array}$ \\
\hline 2013 & 142 & 93 & 34.51 & 91 & 35.91 & 81 & 42.96 & 72 & 49.29 \\
\hline 2014 & 136 & 95 & 30.15 & 82 & 39.71 & 76 & 44.12 & 63 & 53.67 \\
\hline 2015 & 115 & 76 & 33.91 & 75 & 34.78 & 72 & 37.39 & 71 & 38.26 \\
\hline 2016 & 149 & 112 & 46.31 & 80 & 46.31 & 75 & 49.66 & 58 & 61.07 \\
\hline $\begin{array}{c}\text { Average } \\
\text { drop out } \\
(\%)\end{array}$ & & & 35.47 & & 39.18 & & 43.53 & & 50.56 \\
\hline
\end{tabular}


Hence it is seen that the drop-out rate increases progressively from first to fourth visit. This dropout rate at each follow-up visit was found to be statistically significant $(\chi 2=61.106, p<0.001)$.

\section{Discussion}

SAM is a preventable and treatable cause of childhood mortality and morbidity. In our study, the mean age of admitted patients was $17.21 \pm 13.94$ months. Maximum number of children (228 (36.19\%)) were within 12-24 months of age. 481(76.35\%) patients were $<24$ months of age. Similarly, in the studies by Choudhary [7] \& Mamidi [8], majority of patients (96\% and 71\% respectively) were below 24 months. In the first 2 years of life, rapid growth occurs and requirement of substrates for energy and building of tissues also increases, thus deficiency of energy, protein and micronutrients often result in malnutrition. In our study, females were more than males (55.4\% vs $44.6 \%$ ) with a ratio of 1.24:1. Higher number of female patients was also found by Joshi [9] (78\% vs 22\%). Singh [10] and Rao [11] also reported that extent of malnutrition was significantly higher in girls $\mathrm{p}<0.05$ and $\mathrm{p}<0.01$ respectively. All these 3 studies were community based studies. Choudhary [7], Ashraf [12], Tariq [13], Goyal [2], Devi [14] \& Aneja [15] described higher incidence of malnutrition in males $(74.6 \%, 53.7 \%, 54.8,84.3 \%$, $57.7 \%, 55.5 \%$ respectively) in their hospital based studies. They postulated that due to ritual and social norms, parents give more importance and seek medical advice more often for male child. However, our study, despite being a hospital based one, showed higher number of female patients.

In our study, maternal and paternal illiteracy rates were $23.01 \%$ and $19 \% .41 .58 \%$ of mothers studied upto primary school and middle school, $34.6 \%$ studied upto high school and intermediate and only $0.79 \%$ studied upto graduation and beyond. The percentages for fathers being 50\%, 30\%, $1.11 \%$ respectively. Higher illiteracy rates were described by Table 1: Shows the recently published NFHS-4 (2014-2015) data [5] on childhood malnutrition in our state of West Bengal and compares it with NFHS-3 data.

\begin{tabular}{|c|c|c|c|c|}
\hline Characteristics & Urban (NFHS-4) & Rural (NFHS-4) & Total (NFHS-4) & Total (NFHS-3) \\
\hline $\begin{array}{c}\text { Children under 5 years } \\
\text { who are stunted (height- } \\
\text { for-age) (\%) }\end{array}$ & 28.5 & 34.0 & 32.5 & 44.6 \\
\hline $\begin{array}{c}\text { Children under 5 years } \\
\text { who are wasted (weight- } \\
\text { for-height) (\%) }\end{array}$ & 16.7 & 21.6 & 20.3 & 16.9 \\
\hline $\begin{array}{c}\text { Children under 5 years } \\
\text { who are severely wasted } \\
\text { (weight-for-height) (\%) }\end{array}$ & 6.0 & 6.7 & 6.5 & 4.5 \\
\hline $\begin{array}{c}\text { Children under 5 years } \\
\text { who are underweight } \\
\text { (weight-for-age) (\%) }\end{array}$ & 26.2 & 33.6 & 31.5 & 38.7 \\
\hline
\end{tabular}

Exclusive breastfeeding upto 6 months was done in $10 \%$ cases and $90 \%$ were mixed fed. $45.82 \%$ mother practised bottle-feeding and $32 \%$ children received pre-lacteal feeds. The percentages were $32 \%, 35 \%, 39.7 \%, 25 \%$ in the study by Devi [14]. In the study by Tariq [13], $41 \%$ were exclusively breastfed, $32 \%$ were predominantly breastfed and $26.2 \%$ were mixed
Chowdhury [7] (89.3\%mothers and 66.2\% fathers) and Goyal [2] (60.6\% mothers and 39.4\% fathers). This was due to regional variation of literacy rates. Joshi [9] and Mittal [16] described education beyond high school level among $31 \%$ and $21.2 \%$ of mothers of SAM children, which was similar to our study.

We observed that in the enrolled patients, 98.1\% patients belonged to lower socio-economic strata (Kuppuswamy scale III, IV, V). Chowdhury [7], Tariq [13], Goyal [2] and Devi [14] reported $96 \%, 83.6 \%, 76 \%, 89.8 \%$ patients belonging to lower socioeconomic strata. This indicates that poor purchasing power, unavailability of food, improper distributions make the children vulnerable to malnutrition in a deprived community. Sanitation facility was not available in $20 \%$ cases. Devi [14] reported that only $7.9 \%$ of SAM children in his study had sanitation facility.

In $10 \%$ cases, the families were joint and in $51.11 \%$ cases the birth order of the affected child was more than 3. Prevalence of SAM was $52 \%$ in the family have 3 or more children in the study by Chowdhury [7]. Sharma [17] also reported the prevalence of malnutrition to be significantly higher in families having more than 3 children due to lower per capita income and poor childcare practices. $6.35 \%$ of children were unimmunized and $85.71 \%$ were partially immunized in our study. The percentages were $42.7 \%$ versus $44 \%$ and $24 \%$ versus $62.3 \%$ in studies by Chowdhury [7] and Tariq [13]. Thus, failure of complete immunization is associated with SAM. However, Aprameya [18] \& Kumar [19] reported $84.6 \%$ and $42.3 \%$ SAM children were completely immunised in their studies. In our study, $75 \%$ children belonged to rural areas. The NFHS 3 and 4 surveys also shows higher incidence of malnutrition in rural areas (Table 1). According to a UNICEF (United Nations Children's Fund) data, globally, over one-third of children in rural households are malnourished [20].

fed. Aprameya [18] reported exclusive breastfeeding in $20.9 \%$ and bottle feeding in $58.2 \%$ cases. In our study, $81.27 \%$ children had been initiated on complementary feeds when admitted, compared to $63.5 \%$ in the study by Chowdhury [7]. In our study, $9.52 \%$ patients beyond 6 months had not been initiated on complementary feeds, compared to $8 \%$ patients in the study 
by Devi [14]. Over diluted cow's milk was the most common top milk supplementation in our study whereas Chowdhury [7] reported it to be goat's milk. The most common complementary food was khichdi in our study, chapati (hand-made whole wheat flour bread) and rabadi (condensed milk with dried fruits) with rice being reported by Chowdhury [7] \& Rasamia [21]. Aneja [15] also reported khichdi to be the most common complementary food. Adequacy of complementary feeds was found in $30 \%$ children in our study, compared to $53.97 \%$ in the study by Devi [14]. The mean age of starting semi-solid complementary food was $8.5 \pm 2.5$ months in our study and $11.6 \pm 3.53$ months in the study by Chowdhury [7] and 7.04 \pm 2.31 in the study by Devi [14]. Bottle fed babies are more prone to infections due to poor hygienic condition of both bottle and nipple, and high incidence of bottle feeding have been reported by Aneja (28.3\%) [15], Chowdhury (17.3\%) [7] and Rasamia (65.8\%) [21] (Table 8).

Table 8: Comparing the complications and comorbidities among various studies.

\begin{tabular}{|c|c|c|c|c|c|}
\hline Characteristics & $\begin{array}{c}\text { Index study } \\
\text { (\%) }\end{array}$ & $\begin{array}{c}\text { Chowdhury [7] } \\
(\%)\end{array}$ & $\underset{(\%)}{\operatorname{Kumar}[19]}$ & $\begin{array}{l}\text { Tariq [13] } \\
(\%)\end{array}$ & $\begin{array}{c}\text { Devi [14] } \\
\text { (\%) }\end{array}$ \\
\hline Anemia & 74.12 & 85.3 & 88.3 & & 69.2 \\
\hline Vit B deficiency & 41.59 & 40 & 14.4 & & \\
\hline Vit A deficiency & 32.54 & 28 & 5.8 & & \\
\hline Vit $C$ deficiency & 0.63 & 1.3 & 1.9 & & \\
\hline Hypoglycaemia & 3.02 & 21.3 & & 6.8 & \\
\hline AGE & 31.75 & 50 & 33.6 & 30.1 & 14 \\
\hline LRTI & 35.87 & 52 & 27.9 & 26.3 & 63 \\
\hline $\mathrm{TB}$ & 0.63 & 9.3 & 22.1 & 4 & \\
\hline HIV & 0.31 & 4 & 2.9 & & 2.6 \\
\hline Otitis media & 0.79 & 2.7 & & & \\
\hline Measles & 0.63 & 4 & 3.8 & 3.8 & \\
\hline Malaria & 0.31 & & 3.8 & & 0 \\
\hline UTI & 2.38 & 4 & 1 & 2.7 & 1.3 \\
\hline Edema & 5.4 & 14.7 & 27 & & \\
\hline Skin infection & 7.94 & & 18.2 & 16.38 & \\
\hline Hypothermia & 20.31 & & & 11 & 11.5 \\
\hline Hypokalemia & 11.9 & & & 9.58 & 6.4 \\
\hline
\end{tabular}

LRTI (lower respiratory tract infection) was the most common associated infection followed by AGE (acute gastroenteritis) in our study. Chowdhury [7], Tariq [13], Kumar [19] also described similar findings. Most common vitamin deficiency was vitamin B - as also described by Chowdhury [7].

In our study, only $9.44 \%$ SAM children $>6$ months age had $M U A C<11.5 \mathrm{~cm}$. Devi [14] reported sensitivity, specificity, positive predictive value (PPV) and negative predictive value of $44.9 \%, 94.74 \%, 84.62 \%$ and $72.73 \%$ of $11.5 \mathrm{~cm}$ MUAC as a

Table 9: Comparing the outcome at NRC with other studies.

\begin{tabular}{|c|c|c|c|c|c|c|}
\hline Characteristics & $\begin{array}{c}\text { Index study } \\
\text { (\%) }\end{array}$ & $\begin{array}{c}\text { Tariq [13] } \\
(\%)\end{array}$ & $\begin{array}{c}\text { Taneja [25] } \\
\text { (\%) }\end{array}$ & $\begin{array}{c}\text { Aguayo [26] } \\
(\%)\end{array}$ & $\begin{array}{c}\text { Kapil } \\
{[27]}\end{array}$ & $\begin{array}{c}\text { Acceptable } \\
\text { rates as per } \\
\text { Indian ministry } \\
\text { of health } \\
\text { recommendation } \\
\text { (\%) [6] }\end{array}$ \\
\hline Cure & 75.24 & 76 & 53.76 & 65 & 46.8 & $>75$ \\
\hline Defaulter & 13.65 & 1.36 & 7 & 32 & 47.2 & $<15$ \\
\hline Death & 0.63 & & & 0.40 & 1.2 & $<5$ \\
\hline $\begin{array}{l}\text { Length of stay } \\
\text { (days) }\end{array}$ & $20 \pm 3.5$ & & $13.81 \pm 2.73$ & $75.8 \pm 9.4$ & $13.2 \pm 5.6$ & 1-4 weeks \\
\hline
\end{tabular}

diagnostic criteria for SAM. Dasgupta [22] also reported low sensitivity $(17.5 \%)$ and PPV $(30.5 \%)$ of MUAC cut-off value of $11.5 \mathrm{~cm}$. However, Finnish [23] and Bangladeshi [24] studies found $M U A C<11.5 \mathrm{~cm}$ to be a single useful criterion for identifying malnutrition. The mean MUAC in our study was $10.35 \pm 2.45 \mathrm{~cm}$ and $11.32 \pm 1.18 \mathrm{~cm}$ in the study by Taneja [25]. The mean weight gain was $6.99 \mathrm{gms} / \mathrm{kg} /$ day compared to $9.25 \pm 5.89 \mathrm{gram} / \mathrm{kg} /$ day in the study by Taneja [25] and $5.5 \mathrm{gms} / \mathrm{kg} /$ day in the study by Tariq [13] and $2.7 \pm 1.9 \mathrm{gms} / \mathrm{kg} /$ day in the study by Aguayo [26] (Table 9). 
The average drop-out rates for 1st, 2 nd, 3rd, 4 th follow-up visits at 15days, 1month, 3 months and 6 months in our study were $35.47 \%, 39.18 \%, 43.53 \%, 50.56 \%$. The drop-out rates described by Taneja [25] were 9.89\%, 23.07\%, 42.65\% and $61.76 \%$ for the 4 follow-up visits. The low compliance during follow-up visits limits the overall success rate of the programme. Creating a network of outreach workers from the NRCs or selecting volunteers from different localities who can monitor the follow-up dates of the discharged children would help in decreasing the number of drop-outs.

In our NRC, the cure, defaulter and death rates, acceptable weight gain were all within the acceptable rates as per Indian Health Ministry recommendations. Thus, NRCs provide lifesaving care for children with SAM as demonstrated by the high survival rate. However other studies show variable recovery rates at the NRCs and was as low as $37 \%$ and high defaulter rates $[4,10,25,27]$. Hence, NRCs cannot be the only tool to combat malnutrition; linking of NRCs with the community based core model of management of SAM children (as revised by WHO) needs to be done. In this model, most SAM children are treated at home with inpatient care being reserved for those with acute complications, thereby minimizing the cost to families and maximizing access to treatment. The first study on conventional community based management of acute malnutrition programme in India was published by Burza [28] from the state of Bihar. There $57.4 \%$ children were discharged as cure, $36.2 \%$ defaulted, $1.1 \%$ died and mean weight gain was $5.1 \pm 3.7 \mathrm{gms} / \mathrm{kg} /$ day.

The Government of India is currently strengthening the Integrated child development (ICDS) scheme, working on national guidelines on community-based management of severe acute malnutrition in India (CMAM), and allowing controlled use of ready-to-use therapeutic food (RUTF) in a number of states, so that in the years to come, more SAM children can be managed at home. However, in a vast country like India where there is deficiency of community health workers, it would be difficult to monitor the domiciliary care, especially in remote areas- hence it is vital to continue with the functioning of NRCs. India's biggest challenges now are to resource and manage this transition at scale within its health system. India has long way to go and as more studies like this present one is published, it would be more interesting and informative to know about the further developments.

\section{References}

1. International Institute for Population Sciences (IIPS) and Macro International. National Family Health Survey (NFHS-3), 2005-6: India. Vol. I. Mumbai: IIPS.

2. Goyal S, Agarwal N (2015) Risk factors for severe acute malnutrition in Central India. Inter J Medical Sci Res and Prac 2(2): 70-72.

3. Mishra K, Kumar P, Basu S, Rai K, Aneja S (2014) Risk factors for severe acute malnutrition in children below 5 years of age in India: A casecontrol study. Indian J Pediatr 81(8): 762-765.

4. Garg A, Badgaiyan N, Singh K (2013) Integrated program achieves good survival but moderate recovery rates among children with severe acute malnutrition in India. Am J Clin Nutr 98(5):1335-1342.

5. International Institute for Population Sciences (IIPS) and Macro International. National Family Health Survey (NFHS-4), 2014-15: India. Vol. I. Mumbai: IIPS; 2016.

6. Ministry of Health and Family Welfare, Government of India (2011) Operational guidelines on facility based management of children with severe acute malnutrition, New Delhi, India: National Rural Heath Mission, Ministry of Health and Family Welfare.

7. Choudhary M, Sharma D, Nagar RP, Dutt B Nagar T, Pandita A (2015) Clinical profile of severe acute malnutrition in western Rajasthan: A prospective observational study from India. J Pediatr Neonatal Care 2: 00057.

8. Mamidi RS, Kulkarni B, Radhakrishna KV, Shatrugna V (2010) Hospitalbased nutrition rehabilitation of severely undernourished children using energy dense local foods. Indian Pediatr 47(8): 687-693.

9. Joshi S, Walgankar SS (2004) Epidemiology of malnutrition in a rural field practice area of navi Mumbai. Indian J Prev Soc Med 35: 80-84.

10. Singh K, Badgaiyan N, Ranjan A, Dixit HO, Kaushik A, et al. (2014) Management of children with severe acute malnutrition: experience of Nutrition Rehabilitation Centers in Uttar Pradesh, India. Indian Pediatr 51(1): 21-25.

11. Rao S, Joshi SB, Kelkar RS (2000) Change in nutritional status and morbidity over time in preschool children from slums in Pune, India. Indian Pediatr 37(10): 1060-1071.

12. Ashraf H, Alam NH, Chisti MJ, Mahmud SR, Hossain MI, et al. (2012) A Follow-up Experience of 6 months after Treatment of Children with Severe Acute Malnutrition in Dhaka, Bangladesh. J Trop Pediatr 58: 253-257.

13. Syed TA, Naik SA, Wasim RA, Saleem R (2015) Demographic, clinical profile of severe acute malnutrition and our experience of nutrition rehabilitation centre at children hospital Srinagar Kashmir. Int J Contemp Pediatr 2: 233-237.

14. Devi RU, Krishnamurthy S, Bhat BV, Sahai A (2015) Epidemiological and clinical profile of hospitalized children with moderate and severe acute malnutrition in South India. Indian J Pediatr 82(6): 504-510.

15. Aneja B, Singh P, Tandon M, Pathak P, Singh C, et al. (2001) Etiological factors of malnutrition in two urban slums in Delhi. Indian Pediatr 38: 160-165.

16. Mittal A, Singh J, Ahluwalia SK (2007) Effect of maternal factors on nutritional status of 1-5-year old children in urban slum population. Indian J Community Med 32: 264-267.

17. Sharma BL , Suman RL, Goyal S, Sanadhya A (2016) Serum Albumin Levels in Edematous Severe Acute Malnutrition Children Aged 6 Months to 5 Years. International Journal of Biomedical Research 7: 265-268.

18. Aprameya HS, KamathSP, Kini PK, Baliga BS, Shenoy UV, et al. (2015) Socioepidemiological determinants of severe acute malnutrition and effectiveness of nutritional rehabilitation centre in its management. Int J Health Allied Sci 4: 148-153.

19. Kumar R, Singh J, Joshi K, Singh HP, Bijesh S (2014) Co-morbidities in hospitalized children with severe acute malnutrition. Indian Pediatr 51(2): 125-127.

20. (2013) Improving child nutrition: The achievable imperative for global progress, New York: United Nations Children's Fund (UNICEF).

21. Rasamiya SK, Sachdev TR (2001) Nutritional status and feeding practices of children attending MCH centres. Indian Journal of Community Medicine 26: 7-9. 
22. Dasgupta R, Ahuja S, Yumnam V (2014) Can nutrition rehabilitation centers address severe malnutrition in India? Indian Pediatr 51(2): 95-99.

23. Briend A, Maire B, Fontaine O, Garrane M (2012) Mid-upper arm circumference and weight for height to identify under-five high risk malnourished children. Matern Child Nutr 8: 130-133.

24. Ali E, Zacharia R, Shams Z, Alders P, Saloi F et al. (2013) Is mid-upper arm circumference alone sufficient for deciding for admission to a nutritional programme for childhood severe acute malnutrition in Bangladesh? Trans R Soc Trop Med Hyg 107(5): 319-323.

25. Taneja G, Dixit S, Khatri A, Yesikar V, Raghunath D et al. (2012) A study to evaluate the effect of nutritional intervention measures on admitted children in selected nutrition rehabilitation centers of Indore and Ujjain divisions of the State of Madhya Pradesh (India). Indian J Community Med 37(2): 107-115.

26. Aguayo V (2013) Integrated programme achieves good survival but moderate recovery rates among children with severe acute malnutrition in India. American Journal of Clinical Nutrition 2013; 98:1335-1342.

27. http://www.iapsmupuk.org/journal/index.php/IJCH/article/ view/955

28. Burza S, Mahajan R, Marino E, Sunyoto T, Shandilya C, et al. (2015) Community-based management of severe acute malnutrition in India: new evidence from Bihar. Am J Clin Nutr 101(4): 847-859.

\section{Your next submission with JuniperPublishers will reach you the below assets}

- Quality Editorial service

- Swift Peer Review

- Reprints availability

- E-prints Service

- Manuscript Podcast for convenient understanding

- Global attainment for your research

- Manuscript accessibility in different formats

( Pdf, E-pub, Full Text, audio)

- Unceasing customer service

Track the below URL for one-step submission https://juniperpublishers.com/online-submission.php 